\title{
Competencies of Early Childhood Educators in Bangalore According to their Professional Variables
}

\author{
K. Sujeevanamma ${ }^{1}$, Dr. K. Anuradha ${ }^{2}$ \\ ${ }^{1}$ M.Phil, Research Scholar, Department of Homescience, S.V. University, Tirupati, Andhra Pradesh, India \\ ${ }^{2}$ Professor, Department of Homescience, S.V. University, Tirupati, Andhra Pradesh, India
}

\begin{abstract}
The present study was conducted to assess the competencies of early childhood educators according to their professional variables. The study sample were 120 pre-school teachers (60 Government and 60 Private teachers), selected from six ICDS projects areas of Bangalore, Karnataka state using stratified random sampling technique. Self-Evaluation Checklist developed specially for ECE educators was used. Results revealed that the pre-school teachers differed significantly in their educational qualification, experience and training. The results can help to suggest that training for pre-school teachers will have more competencies which intern helps to improve the quality of preschool programme.
\end{abstract}

Keywords: Competencies, Professional variables, Early Childhood Educators

\section{Introduction}

The early years of life are the most crucial periods in a child's life when the rate of development is very high and foundations are laid for cumulative lifelong learning. Over the past several decades, research has clearly demonstrated the importance of early care and education. This is the period during which there are specific sensitive periods for optimal learning in particular areas. During this period of 3 to 6 years a child starts attending the pre-school. Pre-school, Nursery school, ECE centre, ECCE centre, etc., are the different names for the school attended by young children. The enriched experiences can be provided in an ECE centre through the professionally competent Early Childhood Educator.

\section{Early Childhood Educator}

Early childhood educator or the pre-school teacher, who works directly with young children plays an important role in maintaining the quality of ECE programme. The vital relationships between early childhood educators and young children are formed in the daily routines and activities of infant/toddler and preschool settings.

It was reported that high quality early childhood education produces substantial long-term educational, social, and economic benefits with the largest benefits for children occurring when teachers are professionally prepared, implementing the practices and strategies they have learned, and adequately compensated (Whitebook, 2003). The Preschool teacher or Early Childhood Educator plays a significant role in providing optimal learning to young children.The competencies needed to support, plan, and guide children's early learning and development are crucial.

The knowledge, skills, and practices of Early Childhood Educators are important factors in determining how much a young child learns and how prepared that child is for entry into school.

\section{Competencies of ECCE Educators}

Early Childhood Educators are expected to have a deeper understanding of child development and early education issues, so that they can provide richer educational experiences for all children, including those who are vulnerable and disadvantaged, engage children of varying abilities and backgrounds connect with a diverse array of families.

Sheridan (2009) and Samuelsson (2011) also reported that the main importance of staff lies in their effect on the process and content quality of ECCE. The training and education of ECCE staff affect the quality of services and outcomes primarily through the knowledge, skills and competencies that are transmitted and encouraged by practitioners. It is also considered important that staff believe in their ability to organize and execute the courses of action necessary to bring about desired results (Fives, 2003).

Review of research supported showed strong evidence that enriched stimulating environments and high-quality pedagogy are fostered by better qualified staff; and better quality pedagogy leads to better learning outcomes (Litjens and Taguma, 2010). But, in recent times pre schools are established like mush rooms in every nook and corner of towns and cities and teachers who are having less educational qualification without proper training are recruited with less wages. But there is a need to assess their competencies.

With this background the present study was conducted to understand the Early Childhood Educators' Competencies according to their professional variables in Bangalore of Karnataka state. The following are the objectives of the study.

\section{Objectives}

- To find out whether the early childhood educators'competencies differ according to their educational qualification.

- To find out whether the early childhood educators' competencies differ according to their training.

Volume 6 Issue 12, December 2017 


\section{International Journal of Science and Research (IJSR) \\ ISSN (Online): 2319-7064}

Index Copernicus Value (2016): 79.57 | Impact Factor (2015): 6.391

- To find out whether the early childhood educators' competencies differ according to their experience.

- To find out whether the early childhood educators' competencies differ according to their Income.

Based on the objectives the following null hypotheses were framed.

\section{Hypotheses}

- Early childhood educators' competencies did not differ according to their educational qualification.

- Early childhood educators' competencies did not differ according to the training received.

- Early childhood educators' competencies did not differ according to their experience.

- Early childhood educators' competencies did not differ according to their income.

\section{Methodology}

\subsection{Sample}

A Sample of 120 pre-school teachers were selected from both Government (Anganwadi Centres) and Private preschools in Bangalore, Karnataka state, using systematic stratified random sampling method. Among the 6 Government ICDS projects in Bangalore 10 Anganwadi Centres were identified from each project randomly. Private pre-schools nearer to selected Anganwadi Centres were identified purposively and thus, 120 pre-schools (60 Govt and 60 Private) constituted the sample. One teacher from each school was selected and thus the sample included 120 pre-school teachers / ECE educators.

\subsection{Tools}

\section{1) Self-Evaluation Checklist}

To assess the competencies of Early Childhood Educators, Self-Evaluation Checklist was developed by the investigator. Self-Evaluation Checklist consisted of 44 main questions with sub questions. The responses were rated on a three point scale. Depending on the type of answer scoring was given. The expected minimum score was 0 and maximum 219. Maximum score indicates the competencies of ECE educator as highly efficient and minimum score indicates poor efficiency. Reliability and validity were established for the checklist following standard procedures.

2) General Information Schedule

A General Information Schedule consists of Teacher's personal and professional information.

\section{Results and Discussion}

The data collected was pooled and tabulated and subjected to statistical analysis. The distribution of sample pre-school teachers according to their professional variables is given in Table-1.
Table 1: Distribution of sample according to their Professional Variables

\begin{tabular}{|c|c|c|c|c|}
\hline S.No & \multicolumn{2}{|c|}{ Professional Variable } & Number & Percentage \\
\hline \multirow[t]{4}{*}{1} & \multirow{4}{*}{$\begin{array}{l}\text { Educational } \\
\text { qualification }\end{array}$} & $10^{\text {th }}$ Class & 36 & 30.0 \\
\hline & & Intermediate & 18 & 15.0 \\
\hline & & Degree & 48 & 40.0 \\
\hline & & PG \& Above & 18 & 15.0 \\
\hline \multirow[t]{2}{*}{2} & \multirow{2}{*}{$\begin{array}{l}\text { Training } \\
\text { Received }\end{array}$} & Yes & 96 & 80.0 \\
\hline & & No & 24 & 20.0 \\
\hline \multirow[t]{4}{*}{3} & \multirow[t]{4}{*}{ Experience } & $0-2$ years & 30 & 25.0 \\
\hline & & $2-5$ years & 36 & 30.0 \\
\hline & & $5-10$ years & 12 & 10.0 \\
\hline & & $\begin{array}{c}\text { Above } 10 \\
\text { years }\end{array}$ & 42 & 35.0 \\
\hline \multirow[t]{2}{*}{4} & Income & $\begin{array}{c}\text { Below Rs. } \\
8500\end{array}$ & 78 & 65.0 \\
\hline & & $\begin{array}{c}\text { Above Rs. } \\
8500\end{array}$ & 42 & 35.0 \\
\hline
\end{tabular}

From table 1 it is evident that out of the sample teachers 40 per cent were graduates, 30 per cent were having SSC qualification and 15 per cent were postgraduates and having intermediate qualification. With regard to training, majority $(80 \%)$ of the teachers were trained. In terms of experience 35 percent were having more than 10 years of experience and only 10 per cent of the sample was having 5-10 years of experience. When respondents income, was considered majority (65\%) of the teachers were earning below Rs. 8500 , only 35 per cent were earning more than RS. 8500 .

Table 2: Mean and SD values of Early Childhood Educators' Competencies across Types of ECE Centres

\begin{tabular}{|c|c|c|c|}
\hline S.No & Type of ECE Centre & \multicolumn{2}{|c|}{$\begin{array}{c}\text { ECE Educator's } \\
\text { Competencies Score }\end{array}$} \\
\cline { 3 - 4 } & & Mean & S.D \\
\hline 1 & Anganwadi Centre (AWC) & 121.300 & 9.143 \\
\hline 2 & Private School & 110.900 & 19.152 \\
\hline 3 & Total & 116.100 & 15.830 \\
\hline
\end{tabular}

The early childhood educators' competency was measured using self-evaluation checklist. Table 2 shows the mean competency score of the sample pre-schools.

Comparatively the pre-school teachers of anganwadi center scored more than teachers of private pre-schools.

The hypotheses were tested using t-tests and analysis of variance.

The first hypothesis framed was "Early childhood educators' competencies did not differ according to their educational qualification". To test this hypothesis Analysis of Variance was conducted and presented in table 3.

Table 3: Mean scores of Early Childhood Educators' Competencies According to their Educational Qualification

\begin{tabular}{|c|c|c|c|c|c|}
\hline S.No & $\begin{array}{c}\text { Educational } \\
\text { Qualification }\end{array}$ & \multicolumn{2}{|c|}{$\begin{array}{c}\text { ECE Educator's } \\
\text { Competencies Score }\end{array}$} & f-value & Sig. \\
\cline { 3 - 5 } & & Mean & S.D & & \\
\hline 1 & 10th Class $(\mathrm{n}=36)$ & 118.83 & 7.599 & & \\
\hline 2 & Intermediate $(\mathrm{n}=18)$ & 130.33 & 4.311 & & \\
\hline 3 & Degree $(\mathrm{n}=48)$ & 108.38 & 20.008 & & \\
\hline 4 & PG \& Above $(\mathrm{n}=18)$ & 117.00 & 10.494 & $11.411 * *$ & 0.000 \\
\hline & Total & 116.10 & 15.830 & & \\
\hline
\end{tabular}

Volume 6 Issue 12, December 2017 


\section{International Journal of Science and Research (IJSR) \\ ISSN (Online): 2319-7064}

Index Copernicus Value (2016): 79.57 | Impact Factor (2015): 6.391

**significant at 0.01 level. $(\mathrm{p}<0.01)$

From table 3 it is known that teachers differed significantly in their competency scores when their educational qualification was considered. The $\mathrm{f}-$ value was highly significant $(\mathrm{f}=11.411, \mathrm{p}<0.01)$. Comparatively teachers with intermediate qualification scored higher in their competency than others. The reason might be that majority of the teachers with intermediate qualification were mainly anganwadi workers and have undergone training by the Government training institutes, which might have made the teachers to have more competency score. Teachers with degree and above qualification were mainly from Private pre-schools and were having comparatively less score.

Second hypothesis framed was "Early childhood educators' competencies did not differ according to the training received". To test the hypothesis t-test was conducted, table 4 shows the result.

Table 4: Mean scores of Early Childhood Educators' Competencies according to Training and t-value

\begin{tabular}{|c|c|c|c|c|c|}
\hline S. & Training & \multicolumn{2}{|c|}{ Competencies Score } & \multirow{2}{*}{ t-value } & Sig. \\
\cline { 3 - 4 } No & Received & Mean & Std. Deviation & & \\
\hline 1 & Yes $(\mathrm{n}=96)$ & 118.88 & 10.114 & \multirow{2}{*}{$4.086^{* *}$} & \multirow{2}{*}{0.000} \\
\hline 2 & No $(\mathrm{n}=24)$ & 105.00 & 26.706 & & \\
\hline
\end{tabular}

**significant at 0.01 level. $(\mathrm{p}<0.01)$

It is known from the table 4 that early childhood educators differed significantly in their competencies according to the training they received. The t-value was significant (4.086, $\mathrm{p}<0.01)$. Comparatively teachers with training scored more than untrained teachers. Fives (2003), reported that the training and education of ECCE staff affect the quality of services and outcomes primarily through the knowledge, skills and competencies that are transmitted and encouraged by practitioners. Thus training seems to improve early childhood educators' competencies.

Third hypothesis framed was "Early childhood educators' competencies did not differ according to their experience". To test this hypothesis Analysis of Variance was conducted and presented in table 4 .

Table 5: Mean scores of Early Childhood Educators'

Competencies according to Experience and f-value

\begin{tabular}{|c|c|c|c|c|c|}
\hline \multirow{3}{*}{$\begin{array}{l}\text { S. } \\
\text { No }\end{array}$} & \multirow[t]{3}{*}{ Experience as Teachers } & ECE E & cator's & \multirow{3}{*}{ f-value } & \multirow[t]{3}{*}{ Sig. } \\
\hline & & \multicolumn{2}{|c|}{ Competencies Score } & & \\
\hline & & Mean & S.D & & \\
\hline 1 & $0-2$ years $(n=30)$ & 119.80 & 11.351 & \multirow{5}{*}{$14.587 * *$} & \multirow{5}{*}{0.000} \\
\hline 2 & $2-5$ Years $(n=36)$ & 104.00 & 20.834 & & \\
\hline 3 & $5-10$ Years $(n=12)$ & 128.00 & 3.133 & & \\
\hline 4 & Above 10 Years $(n=42)$ & 120.43 & 7.985 & & \\
\hline 5 & Total & 116.10 & 15.830 & & \\
\hline
\end{tabular}

It is clear from the above table that the sample preschool teachers differed significantly in their competency score depending on their experience. The f-value 14.587 was significant at 0.01 level. The teachers having more experience scored higher competency score than teachers with less experience (below 5 years).
Fourth hypothesis framed was "Early childhood educators" competencies did not differ according to their income". To test the hypothesis t-test was conducted, table 4 shows the result.

Table 6: Mean scores of Early Childhood Educators'

Competencies according to Income and t-value

\begin{tabular}{|c|c|c|c|c|c|}
\hline S.No & $\begin{array}{c}\text { Income } \\
(\mathrm{Rs})\end{array}$ & \multicolumn{2}{|c|}{$\begin{array}{c}\text { ECE Educator's } \\
\text { Competencies Score }\end{array}$} & \multirow{2}{*}{ t-value } & \multirow{2}{*}{ Sig. } \\
\cline { 3 - 5 } & & Mean & S.D & & \\
\hline 1 & Below 8500 $(\mathrm{n}=78)$ & 115.85 & 18.090 & \multirow{2}{*}{$0.238^{@}$} & \multirow{2}{*}{0.812} \\
\hline 2 & Above $8500(\mathrm{n}=42)$ & 116.57 & 10.599 & & \\
\hline
\end{tabular}

@ - Not significant;

It is observed from table 6 that the sample preschool teachersdid not differ significantly in their Competency score according to their income (salary). The t-value 0.238 was not significant.

From the above discussion the following conclusions were drawn.

\section{Conclusions}

- The sample early childhood educators / preschool teachers scored moderately good competency score.

- The sample early childhood educators / preschool teachers differed significantly in their competency score according to their educational qualification, experience and training.

- Comparatively Anganwadi teachers who have training scored good competency score.

\section{Implications}

The results of the present study revealed that early childhood educator's competencies differed significantly according to their educational qualification, training and experience. Teachers with training scored more competencies score than untrained teachers. Hence, while appointment of pre-school teachers, taking care of training aspect helps not only to provide optimal learning opportunities to young children, but also to improve the quality of pre-school programme.

\section{References}

[1] Fives, H. (2003). What is teacher efficacy and how does it relate to teachers' knowledge? A theoretical review, Paper presented at the American Educational Research Association Annual Conference, Chicago. Retrieved from

http://www.scirp.org/(S(lz5mqp453edsnp55rrgjct55))/ref erence/ReferencesPapers.aspx?ReferenceID=2109039

[2] Litjens, I. and Taguma, M. (2010). Literature overview for the 7th meeting of the OECD Network on Early Childhood Education and Care, OECD, Paris. Retrieved from

http://www.oecd.org/education/school/50165861.pdf

[3] Pramling, N. and Samuelsson, P.I. (2011).Educational encounters: Nordic studies in early childhood didactics. Dordrecht, The Netherlands: Springer. Retrieved from https://www.researchgate.net/publication/265235924_Ed ucational_encounters_Nordic_studies_in_early_childhoo d_didactics 


\section{International Journal of Science and Research (IJSR) \\ ISSN (Online): 2319-7064}

Index Copernicus Value (2016): 79.57 | Impact Factor (2015): 6.391

[4] Sheridan, S. (2009). Discerning pedagogical quality in preschool. Scandinavian Journal of Educational Research, Vol. 53 (3), 245-261.

[5] Whitebook, M. (2003). Early education quality: higher teacher qualifications for better learning environments- a review of the literature. institute of industrial relations, University of California,

Berkeley.Retrievedfromhttp://cscce.berkeley.edu/files/20 03/Early_Ed_Quality.pdf

Volume 6 Issue 12, December 2017

www.ijsr.net 